McCorkle, W., Problematizing Immigration Restrictions

\title{
Problematizing Immigration Restrictions during COVID-19 in the Social Studies Classroom
}

\author{
William McCorkle \\ College of Charleston \\ *Corresponding Author: mccorklewd@cofc.edu \\ Received : 2020-07-29 \\ Rev. Req. : 2020-08-25 \\ Accepted : 2020-09-27
}

DOI: $10.46303 /$ ressat.05.03.1

\begin{abstract}
How to cite this paper: McCorkle, W. (2020). Problematizing Immigration Restrictions during COVID-19 in the Social Studies Classroom, Research in Social Sciences and Technology, 5 (3), 1-24. https://doi.org/10.46303/ressat.05.03.1

This is an Open Access article distributed under the terms of the Creative Commons Attribution 4.0 International license (https://creativecommons.org/licenses/by/4.0/)
\end{abstract}

\begin{abstract}
In the midst of the COVID-19 pandemic, which affected almost every corner of the globe, nations largely closed their borders and restricted or completely halted immigration. This stance, while understandable, raises questions about how ideas of inclusivity and immigrant rights can be maintained in the midst of chaos and insecurity. This article based in the framework of critical border and migration studies provides an overview of the evolution of immigration policies during the crisis and examines how social studies teachers can problematize assumptions of restrictive immigration policies during times of uncertainty and connect the current situation with past times of crisis. Though this is relevant to teachers from all countries, there is a particular focus on the United States context. Central to the argument is that the ideals of a more open and inclusive immigration system must be maintained even during times of fear and panic. This work builds upon pedagogical scholarship on immigration in the social studies classroom while applying these ideas to the problematic and unique circumstances of immigration during a pandemic.
\end{abstract}

Keywords: immigrant rights; critical migration; social studies pedagogy; COVID-19

\section{Introduction}

It would be an understatement to say that life has changed for everyone during the COVID-19 (Coronavirus) pandemic in 2020. Basic aspects of life such as employment, schooling, and even family gatherings have changed for most people. In this chaotic time when fear is abounding, it is natural for people to focus on the dramatic changes in the daily lives of their families. In the midst of these changes, areas such as immigrant rights have garnered less coverage, and in the process, have suffered serious setbacks.

Many educational scholars and activists are arguing for a deeper exploration of immigration in the classroom and educational research particularly in the rise of more xenophobic 
McCorkle, W., Problematizing Immigration Restrictions

movements, particularly in the United States with the election of Donald Trump (Dabach et al., 2018; Poteat et al., 2019; McCorkle, 2018b). Though structural injustices in the immigration system existed far before Trump, the more blatant forms of prejudice have been revealed more clearly in this administration, whether it was the child separation policy (Holpuch, 2020), the "remain in Mexico" policy (Hurley, 2020), or the Muslim travel ban (Lind, 2018). While opposition to these policies had been somewhat vocal (Kocher, 2018; Lind, 2018), those voices have become less strident in a time of pandemic and chaos like COVID-19.

During the COVID-19 pandemic, the restrictions on immigration have reached levels that few could have not imagined before. Many nations completely closed their borders to nonresidents (Asquith, 2020), which affected both broader travel and immigration. The United States went beyond merely stopping non-essential travel and also prevented the entrance of new asylum seekers and refugees (Alvarez, 2020a, Human Rights Watch, 2020) with little protest. They even started deporting unaccompanied minors (Montoya-Galvez, 2020), a policy that even the Trump administration was hesitant to implement previous to the pandemic. While traditionally many on the political right would applaud these measures, there seemed to be little resistance from the left. The attitude among some almost seemed to be that in the midst of the perceived inaction of President Trump, at least he was being strict or "responsible" in regard to this area of COVID-19 preparedness. How do educators respond in such a time as this? How do they ensure that these types of pandemic related immigration restrictions are only temporary and do not become endemic? This paper considers how educators, particularly social studies teacher educators, can intentionally stress the values of a more open and inclusive immigration system in the midst of chaos, fear, and pandemics using the framework of critical border and migration studies and through an understanding of the broader literature on teaching about immigration within the classroom. As Tarman (2020) highlights, this pandemic has caused individuals to call into question some of the current social structures and inequities. The contention of this article is that the current restrictive immigration system, exacerbated by the current crisis, must be included in that broader critique. Both this critique and ideas for integrating these ideas that problematize the restrictions within the classroom are central in this article.

\section{Theoretical Framework}

This paper is centered on the ideas of critical border and migration theories (Juss, 2004; Parker \& Vaughan-Williams, 2009; Schulze-Wessel, 2016) particularly as it relates to the social studies (McCorkle, 2020). Though these theories can be defined in different ways and have distinctive terms, the core idea revolves around "the work that borders do as foundations linked to violence, force, and the deployment of a logic of exceptionalism" (Parker \& Vaughn-Williams, 2009, p.585) and whether "nation-states have the right to restrict migration, outside of general, reasonable security measures" (McCorkle, 2020, p. 63). Parmar (2020) contends that borders should be reimagined as reflections of the societies that produce them as this "may inspire society to hold a mirror to itself and reveal its insecurities and obscurities toward those deemed to be 'strangers" (p. 14). 
McCorkle, W., Problematizing Immigration Restrictions

Authors such as Carens (1987) have compared restrictive migration to the feudal system where individuals are born on a plot of land and then forced to remain there throughout their lives. He asks if we see feudalism as so unjust, why do we not see restrictive migration in the same way? These theories also relate to more open border theorists like Bregman (2016) who argue that more open borders would not only be the best solution to poverty in developing countries but would also confront what he sees as the greatest form of discrimination, an individual's place of birth. Carens (1987) contends that though open immigration may not be able to be implemented immediately, it should be a goal developed nations work towards as it is the only morally justifiable response. Bregman (2016) and Storesletten (2000) argue that more open immigration system would not only benefit those coming from the developing world but could also be beneficial to industrialized nations.

Schulze-Wessel (2015) examines the economic disparities in regard to immigration as the borders are more open to those who are affluent but are often closed to those who are impoverished. In a similar vein, Fortier (2006) explores how migration for poor communities who are most restricted is also a necessity for them rather than a sign of "hyper-mobility" that often defines migration for wealthier individuals (p. 318). For many this mobility is seen as a right, but it is applied unevenly based largely on wealth. Basik (2012) also describes the injustice of limiting migration as poor immigrants who need to leave their countries are often the victims of international economic policies that put them at a disadvantage. There is something uniquely unjust about allowing capital to easily pass through borders while not allowing the same for labor. He further argues that most of the research in immigration has focused on immigration from a national economic perspective rather than from the individual, human rights perspective. It could also be argued that a more open immigration system can help improve globalization (Pyun \& Lee, 2009) and ideas of global citizenship (Banks, 2003), which can have a strong influence on peace and understanding between those of difference cultures and nationalities. Mezzadra (2020) and McCorkle (2019) also call for a new vision of borders and migration through the lens of freedom. As Mezzadra states, "A politics of freedom of movement must take seriously the proliferation of borders beyond territorial demarcations" (p. 14). These theories are particularly marginalized and forgotten during a pandemic, but times of chaos are when these critical theories are particularly important because the already restrictive immigrant system becomes even more inaccessible.

\section{Literature Review}

There is significant academic literature on teaching about immigration within the classroom, particularly in the social studies classroom. Authors such as Dabach, Merchant, and Fones (2018) argue that in the classroom immigration should be taught less as controversy and more as something that is quite natural throughout history. When framing immigration in terms of controversy, we automatically undermine it as an issue of basic human rights, which should be at the center of the discussion. Tarman and Gürel (2017) explore Turkish social studies candidates' awareness and attitudes towards refuges in their country. They argue that there is a lack of focus on refugee issues in the social studies, and though there were inclusive attitudes among the pre-service candidates overall, there tended to be more exclusive attitudes toward 
McCorkle, W., Problematizing Immigration Restrictions

having refugees settle in their own area. Aydin et al. (2017) argue that teachers should receive greater training to ensure that they are creating a welcoming environment for immigrant and refugee students in their class and eliminating some of the biases they may have towards these students.

Nast (2012) outlines lesson plans that can be taught about issues regarding refugees. Some examples include focusing on the story of a young Iraqi refugee and having students explore Article 13 of the Universal Declaration of Human Rights and how it applies to Palestinians in particular. From a slightly different perspective, White (2004) describes how educators can use content analysis to have students analyze U.K. newspapers clippings from the $20^{\text {th }}$ century in relation to asylum and immigration policy. Monreal and McCorkle (2020) analyzed the state social studies standards and three middle school social studies textbooks in a U.S. southern state and conclude that while historical immigration is seen as natural, more modern immigration is often portrayed as something that is controversial. Additionally, textbooks tended to link undocumented immigration with criminal activity. Overall, there was a lack of actual coverage about modern immigration. McCorkle (2018a) also argues that it is vitally important that teachers are the ones seeking to undermine xenophobic ideas and narratives that will not likely be significantly challenged outside of this academic setting. This is particularly relevant to three of the most common narratives - that undocumented immigrants place a burden on the economy, that immigrants have higher crime rates, and that immigrants are over-running our border like never before (McCorkle, Spearman, \& Cole, 2018). Journell and Castro (2011) examine how immigration was used as a "catalyst" for discussing civics education during the 2008 election. Among other themes, the teacher in the study had students consider how policies like deportation seemed to be in contradiction to ideas like natural rights (p.13). Likewise, Dabach, Fones, Merchant, and Adekile (2018) discuss how social studies teachers are able to bring in the idea of civic participation for undocumented students while remaining unabashed in their support for the students. This article builds on this research but also takes a unique perspective as it seeks to understand how immigration should be discussed in unprecedented times, when migration and human movement in general is seen as hazardous.

\section{Restrictive Immigration in Times of Crisis}

In times of crisis, nations tend to be more insular and to marginalize foreigners, whether those actions will lead to greater security or not. In certain instances, these types of actions are counterproductive to the host country. A relevant though indirect analogy was when the United States sought to impose high tariffs at the start of the Great Depression and caused greater economic disaster (Crucini \& Kahn, 2003). The Red Scares of the 1920 s and 1950s, particularly related to the fear of foreign subversives, caused the United States to abandon many of its core constitutional values related to freedom of press, assembly, and speech. In a similar way, the earlier Alien and Sedition Act in 1798 raised concerns that too much power was being put in the hands of the executive branch and taking away from the broader rights of migrants (Bradburn, 2008). There is also the example of $9 / 11$ where more stringent immigration restrictions were implemented under the rationale of stopping another terrorist attack. It is difficult to say whether these greater restrictions were a reason that there were no large-scale 
McCorkle, W., Problematizing Immigration Restrictions

terrorist attacks by foreign nationals or whether they were irrelevant in that matter. What is clear is that the restrictions affected many people who posed no threat, justified greater immigration restrictions, and in many ways created the immigration restriction apparatus in the United States (Garreton, Ryan, \& Carmel, 2020). In fact, many could argue that the xenophobic sentiment under people like Trump has at least part of its roots in the fear of a foreign threat from 9/11 (Rhodes, 2020) even if none of the individuals that committed the acts had crossed illegally into the country. This is related to the larger anti-globalist and nationalist populist movements that have risen in many countries throughout the globe over the last decade whether that is in Brazil, Hungary, Great Britain, or Italy. As White (2020) highlights, much of the populist reaction is in response to globalism, particularly the negative economic ramifications that affect segments of the society. Galston (2017) discusses how the Great Recession and the growth of technologies have played a role in this new populist movement, particularly in the United States.

\section{Immigration Restrictions and COVID-19}

The current situation with the COVID-19 pandemic is on a scale that we have not faced in any of our lifetimes. Outbreaks like the Avian flu were not treated in the same way and did not lead to dramatic immigration restrictions. Likewise, the Hong Kong flu in 1968 did not lead to the same level of social distancing or restrictions on borders. Even in the Spanish flu of 1918, there was not the same level of global border restrictions. There can be a couple of factors involved with this difference from 1918: first, due to the differences in transportation and technology, there was not the same ease of travel between borders like today. Also, there was less of a system in place to limit immigration. For example, in the United States, even during this period of World War I, the border was much more open than it is today (Ngai, 2014). It was much harder to make a decree and shut down the borders to the outside world. With that stated, there was discrimination against certain immigrants, particularly the Chinese who were accused of spreading the Spanish flu (Kraut, 2010).

The question of whether these stringent immigration policies both in the United States and globally have been effective will be up for broad debate and will be largely speculative in nature. On one hand, it appears rational that halting travel from China or Italy at the beginning of the crisis or stopping travel from the United States later in the crisis may have stopped the spread of the virus. This is a problematic reality from a more critical border perspective particularly with the need to reframe immigration as an issue of freedom (Mezzadra, 2020). It does problematize this critical perspective and seems to bolster the idea of more restrictive borders. However, there are also aspects where the closing of the borders needs to be critiqued. For example, later evidence showed that COVID-19 was in places like France (Tidman, 2020) and California (Chiu \& Armas, 2020) months before the extent of the spread was realized and the borders were closed. At this point, did the closing of the borders actually solve many of the issues? Did the possible mitigation from restrictions on the few people that were going to still be traveling justify the restrictions in travel? Furthermore, there were many instances where the restrictions on the borders did little to stop the spread, such as the United States placing further restrictions on those from Central American and Mexico where the rates from COVID- 
McCorkle, W., Problematizing Immigration Restrictions

19 were much smaller. Even in the summer of 2020 when the United States leads the world in COVID-19 cases and deaths, there are still broad restrictions on individuals from countries that have a fraction of the number of cases. For example, as of August 2020, the United States had 10 times the number of official COVID cases as Mexico even though the population is only about three times as large (Statista, 2020).

The larger question is when will these restrictions be lifted. This article is being written in the summer of 2020, so at this time this question is still unknown. For example, even at a time when and if a vaccine is found, will immigration restrictions still be in place because those from developing nations may have less access to the vaccine? At what level of spread will it be considered safe to admit people from a foreign country? What would happen in places like the United States or Europe where some people may doubt the numbers coming from more authoritarian countries such as China, Russia, or Iran? This pandemic is occurring during a time where simultaneously there has been more travel for those in the wealthier classes but also greatest restrictions for many immigrants, particularly for those that do not come from wealth (Fortier, 2006; McCorkle, 2020). Will the effects of this virus exacerbate this trend?

\section{Threats to Globalism}

Though globalism has been used at times by those in power to oppress marginalized groups in both the developed and developing world, it could also be argued that the internationalism and interchange of the world has meant a more peaceful world (Girdap, 2020; Kilinc et al., 2018; Pyun \& Lee, 2009). The more open borders of the E.U. have been a sign of the positive change from conflict that not only defined Europe during World War I and World War II, but also throughout much of its history. The pictures of the borders being resurrected in Europe in many ways symbolize a mitigation of the dream that was birthed out of the formation of the European Union at the end of World War II and the more open borders that the Schengen Agreement created (Pallini, 2020). Even as those restrictions are once again lifted, what it has shown is that the freedom and unity of the borderless Europe may have always been an illusion. The borders can be raised again whenever it is seen as necessary.

It is also important to consider how the business relationships and personal interchange between nations may help lead to greater international cooperation. Though COVID-19 may not shut down the economic activity between powerful nations, global cooperation goes beyond the exchange of products. It means Americans living and traveling in China, foreign exchange students coming to the United States and Canada, and the yearlong foreign work experiences that change worldviews forever. Though most of these experiences are the privileges of those living in the developed world or among the wealthy in the developing world, we should not underestimate the power they have for greater cooperation and peace. Countries with not only economic ties but social and cultural ties are more likely to find productive ways to interact (Woods, 1987). 
McCorkle, W., Problematizing Immigration Restrictions

\section{The U.S. Pandemic Travel Policies}

The U.S. policy changes towards immigration during the COVID-19 epidemic is a good case study to examine. The first real restrictions came when President Trump called for a travel ban from China when the epidemic first began. This ban was announced on February 2, 2020, and applied to non-citizens flying directly from China to the United States; though there were loopholes to true containment as U.S. citizens and residents returning from China were still allowed to re-enter (Yen, 2020). Many people including Jennifer Nuzzo, a professor of health security at John Hopkins and Ron Klain, the former Ebola 'Czar' for the Obama administration questioned the wisdom or effectiveness of the measure (Kessler, 2020). Both top Democratic presidential candidates, Joe Biden and Bernie Sanders, seemed to be critical of Trump's move to shut down travel from China (Re, 2020). The initial move to restrict immigration was met with resistance; however, as the toll of the virus became greater much of that resistance decreased.

On March $12^{\text {th }}$ President Trump announced the next step of restrictions targeting foreign nationals coming from the Schengen Zone of Europe. As Saeed (2020) highlights at least part of the reason for this move may have been to refocus the controversy on the actions of other foreign nations for not taking the needed precautions to stop the spread of the virus. This came at a time when there was growing anger and frustration at the president for not doing more to stop the virus. The European travel ban could have been a way to both show action while at the same time putting the blame more on a foreign entity. Curiously, Ireland and the United Kingdom were originally spared from the ban but then were added to the ban two days later (Snyder, 2020). This relates to the broader idea of the threats primarily residing outside our border (or those foreigners coming in) when in reality the threat was already inside. This is a populist trope employed in both in modern and historical narratives (McCorkle, Spearman, \& Cole, 2018). Though overall in the American society the idea of shutting down borders may have been more embraced, as the fear from COVID-19 had become central in the American consciousness, there was strong critique from some in Europe. Amaro (2020) highlights some of the critiques of this policy from those in Europe including those who considered that it was more political than strategic and according to a leader at one Brussel's based think tank it was an "effort by Trump to try to convince the American people he has a plan." The presidents of the European Council and European Commission were direct in their condemnation of the situation was handled. As they stated,

The Coronavirus is a global crisis, not limited to any continent and it requires cooperation rather than unilateral action. The European Union disapproves of the fact that the United States decision to impose a travel ban was taken unilaterally and without consultation. The European Union is taking strong action to limit the spread of the virus (von der Leyen \& Michel, 2020).

Refugees were also a target of the restrictions. The initial refugee ban from the United States was only supposed to last for about two weeks from March $19^{\text {th }}$ through April $6^{\text {th }}$ (Alvarez, 2020a). However, like many of the policies, the restrictions for refugees continued to be 
McCorkle, W., Problematizing Immigration Restrictions

expanded and was not lifted until the end of July 2020. These restrictions were implemented in a refugee program that was already accepting record low numbers (Alvarez, 2020b).

Later, on March 21 $1^{\text {st }}$, Trump further shut down the Mexican American border, blocking any non-essential travel; this initial shutdown was expanded an additional month in April. A similar move was made with the shutting down of the Canadian border (Romo, 2020). Shutting down the U.S.-Mexico border had a dramatic impact on asylum seekers. Though many adults and families were blocked from asylum due to the United States Migration Protection Protocol (Remain in Mexico Policy), the latest policies under COVID-19 have meant that even unaccompanied minors are being denied a chance for asylum (Greene, 2020). As Greene highlights, though the U.S. and Mexican governments deny direct coordination in stifling the movement of asylum seekers, they are both working together to ensure that it is more difficult to pursue asylum. In one story she recounts how three minors were grabbed by Mexican officials as they were seeking to cross into the country. In July of 2020, it was also reported that the Trump administration was working with several hotel chains to temporarily house unaccompanied minors before they were deported (Merchant, 2020).

The Trump administration's stance towards asylum seekers did face some greater pushback. As the UN Refugee Agency stated,

"We understand that in the current global Covid-19 public health emergency all governments have an obligation to enact measures to protect the health of their populations. While this may warrant extraordinary measures at borders, expulsion of asylum seekers resulting in refoulement ${ }^{1}$ should not be among them (Lakhani, 2020).

Lucas Guttentag (2020) argues how this initial order came from the Centers for Disease Control and is an abuse of the power and unlawful under current immigration statues and international law. As he states, "The COVID border ban attempts to erect a shadow immigration system devoid of constitutional protections that erases fundamental statutory safeguards implementing refugee protection obligations." In this way the ban went far beyond a temporary necessity during a pandemic and help to further strengthen the more heavy-handed antiimmigrant policies of the executive branch, particularly under the Trump administration.

President Trump took the restrictions even further in April 2020 when in a late night tweet, he stated that he was going to ban immigration into the United States, with no distinction due to the rates of COVID-19 in the foreign countries, to deal with the spread of the disease and the economic turmoil that it was creating. He later backtracked the dramatic comment and stated that it would only apply to new green card holders for 60 days with a possible extension in the restriction if necessary (Shear, Kanno-Youngs, \& Dickerson, 2020).

\footnotetext{
${ }^{1}$ Refoulement refers to return refugees or asylum seekers to nations where they may face persecution, torture, or other human rights violations. It is considered illegal under international policy (UN Human Rights Office of the High Commissioner, N.D.).
} 
Something that needs consideration is that throughout all these restrictions, the name Donald Trump has been used over and over again. Though the Constitution does not give the president the ultimate authority over immigration policy this has become largely the case, not only in the times of pandemic, but also more broadly (Anderson, 2020). This includes polices that were more inclusive of immigrant rights such as DACA and DAPA under President Obama, but also a host of restrictive policies from the Trump administration before the pandemic. It has almost been taken for granted that the executive branch has this power when that is far from settled from a legal perspective (Wilson, 2019).

\section{International Immigration Restrictions}

The pandemic has also marginalized immigrant communities globally accused of being the cause of COVID-19 spread in some nations. This was particularly the case in Singapore where approximately $85 \%$ of the cases of COVID-19 in the nation came from the cramped dorms of low waged migrants. In these dorms 10-20 individuals can stay in one room, which is an obviously unsanitary situation with the spread of the virus (Leung, 2020). A similar situation occurred in Saudi Arabia where around 75\% of the country's COVID-19 cases came from the migrant populations. As the International Labor Organization notes, many migrants may refuse to take part in the free testing from the nation out of a fear that they could be deported if their residency had previously expired (Sherlock, 2020).

One of the worst examples of the treatment of migrants during this time was in the country of Malaysia where hundreds of undocumented migrants were rounded up and placed in detention out of the fear that they would spread the virus. The United Nations warned Malaysia to not put these individuals in detention as it could increase the risk of the virus spreading. People also fear that these policies will cause migrant communities to go into hiding and likewise cause greater issues with the virus. The majority of the migrants targeted are from the persecuted Rohingya group. The Asian chapter of the Human Rights Watch has argued that "This is perhaps the most mindless and inane thing 'they' could have done." However, the government is "committed to promoting a policy of fear and xenophobia that transfers the anger of the Malaysian public on to foreigners who cannot defend themselves." (Ahmed et al., 2020).

\section{Examples of More Inclusive Policy}

There have been some examples of nations and states that have acted more inclusively towards migrants during this crisis. The country of Portugal has ensured that undocumented immigrants receive the same rights as permanent residents such as access to public health care and welfare benefits for at least the initial months of the crisis (Schmitt \& Massimino, 2020). This stands in contrast to the United States, which did not initially allow undocumented immigrants or even those with Temporary Protected Status or Deferred Action for Childhood Arrivals (DACA) status to receive federally funded free COVID-19 testing (Schmitt \& Massimino, 2020). However, 
McCorkle, W., Problematizing Immigration Restrictions

bucking the national policy, the state of California has also offered $\$ 75$ million in COVID testing for undocumented immigrants in the state (Jordan, 2020).

\section{Excessive Restrictions}

Though most individuals would agree that some of level of travel restrictions may have been necessary particularly in the beginning of the crisis when containment of the virus was the primary goal, the broad and unbending immigration restrictions that have continued far surpass reasonable regulations and are being used to cover more anti-immigrant policies that politicians would like to enact. In the case of the United States, the obvious opportunism on COVID-19 is quite blatant. The same administration that is calling for schools to be opened across the nation and even threatening federal funds if this does not occur (Guadiano et al., 2020) is simultaneously enacting policies that imply children crossing the border for asylum are a public health concern. Likewise, little distinction is being made between those who are merely traveling for pleasure versus those such as asylum seekers and refugees whose lives and safety lie in the balance. Finally, the prolonged closure of borders reveals how the free movement of people is not seen with the same level of importance as other areas such as opening back businesses and schools or allowing social events to resume. This underlies the disregard of the importance of the rights of migration.

\section{Classroom Strategies}

In the coming years, whether classes are conducted in person or online, many issues regarding COVID-19 will surely be central in the discussion in the social studies classroom. Issues such as the economy, public health, and civil liberties will certainly be core topics, but it is also important in this context for teachers to center the issue of immigration. For social studies teachers in particular, the focus on overly restrictive immigration and the use of crises to promote xenophobic narratives and policies is particularly related to history and contemporary political issues. In particular, this theme relates to the National Council for the Social Studies (2010) curriculum standard \#3 on people, places, and environments, which includes the study of "the causes, patterns and effects of human settlement and migration." This area would primarily apply to the secondary classroom. However, there could also be application at the middle grades and elementary level if the relevant adaptions were implemented. For many students, immigration might not have been a topic that they have even considered in the context of COVID-19. Part of this exploration could just be having students examine articles and primary sources related to this topic both in the United States and around the world. Some examples include coverage from the U.S.-Mexico border with the fear of COVID-19 (Peña, 2020) or stories of refugees being delayed because of the new policies.

This article is based more in a critical approach, aligned with teaching methods explicitly working for social reconstruction such as represented by educational philosophers like Counts (1932/1978) and Freire (1970/1986). However, the ideas raised in this article could also be applicable for teachers who would take an approach more akin to John Dewey (1897) who was more reticent in seeking to persuade students towards a certain position. In this case, the 
McCorkle, W., Problematizing Immigration Restrictions

arguments and questions raised in this piece would be relevant in having the students begin to grapple with this issue.

It is important for teachers who are discussing these issues, both during the pandemic and in future reflective retrospectives, to consider the ways that immigrants were treated during COVID-19 and how we can ensure the creation of more inclusive policies during future pandemics or other crises. Four possible strategies include questioning or problematizing the immigration policies during COVID-19 (especially the ones that may have been excessive or unnecessary), introducing ideas on rights of migration both within and outside national boundaries, linking the current immigration restrictions to the reactions of the U.S. government to past crises, and exploring the link between immigration restrictions and excessive executive power.

\section{Questioning the Policies}

One strategy that educators could implement is having students truly consider some of the wisdom of the immigration restrictions during the pandemic. If educators accept the simplistic stance that all border closings are justified in the name of stopping the virus, it could set up a damaging precedent during a precarious worldwide event or unrest. For example, it might have made perfect sense for the United States to put greater restrictions or even outright bans on individuals from some nations in Europe, particularly Italy, in the early days of the violence. However, was a complete E.U. ban justified, especially as the rates in the United States were also high when this ban was issued? It made even less sense in May 2020 when there was still a ban of individuals from European countries when the United States led the world in COVID19 cases but was still refusing entrance of individuals from Europe. Were the further restrictions of the southern border, when Mexico and Central America had far fewer cases than the United States, just a convenient method for the country to implement more xenophobic policies? As educators look back on this crisis after the initial panic has subsided, these are the issues that should be considered. Many citizens who lean left politically, who may have traditionally advocated for more open border but supported these decisions either explicitly or implicitly as a way to mitigate the spread of the virus, may have done so without realizing the precedent that it is setting for every future world crisis. Students could engage in a type of counterfactual history (Bunzi, 2004; Roberts, 2011) and speculate what the similarities and differences would have been if borders and migration were allowed to remain relatively the same. Though students may come to different conclusions, this approach of deconstructivity at the minimum could problematize the normalization of some of these extraordinarily stringent policies, which were almost universally embraced. This area could also be enhanced with having students consider some broader questions including,

1. What should be the duties of nations towards asylum seekers and refugees? What are the actual written international and national polices?

2. What level of travel restrictions are reasonable and justified during a global pandemic? Should there be exceptions to these restrictions?

3. What is the proper balance between a nation's public health in a pandemic and the rights of refugees and asylum seekers? 
McCorkle, W., Problematizing Immigration Restrictions

4. What would be the effect of maintaining the current restrictive immigration policies after the pandemic has passed?

\section{Rights of Migration}

Teachers also can help students analyze how this crisis relates to the rights of migration in general. This has come into clearer focus as now countries have even restricted travel from the United States, most notably the EU (Chappell, 2020). This is largely something that those from the United States have never experienced. A U.S. passport normally grants almost open access, at least for tourist travel, to most nations in the world. However, the United States (and other developed nation) largely exclude those from poorer countries (Schulze-Wessel, 2016). This comes into even greater focus after there was some discussion in late March by the Trump administration to even block travelers from leaving infected states like New York (Alper, 2020). Though this action did not occur, there were other states that put restrictions on individuals from areas like New York and New Jersey. South Carolina banned residents from the New York tri-state area from reserving hotel rooms in the state (Kelleher, 2020). Other states like Rhode Island went a step further and actually had officials pull over cars and have police and National Guard knock on doors for individuals coming from New York to make sure they were in quarantine (Nieto del Rio \& Ellis, 2020). In the summer of 2020, the roles were reversed as New York, New Jersey, and Connecticut put quarantine restrictions on individuals from many Southern and Western states (Coleman, 2020). These are types of restrictions on intra-national movement that have not really been seen in the history of the country, even during the 1918 pandemic.

Perhaps these novel developments can be a good point of classroom focus in helping students reimagine the rights of migration in general. Should educators perhaps discuss if these restrictive actions, which are seen as draconian in times of crisis, should be removed as the norm for people from poor countries in general? There is something that seems instinctually wrong with a family not being able to leave their state and go to another. Why then do we allow such restrictions to take place between countries when the stakes are often much higher (McCorkle, 2019)? Students could examine some of the issues that could result if districts, states, or provinces within a country began to implement restrictions on internal migration more fully. In China, rural residents were barred from obtaining particular government benefits and even certain jobs if they relocated to urban areas (Scheineson \& Zissis, 2009). Though these restrictions are becoming more liberalized, there remnants still exist (Candelaria, Daly, \& Hale, 2013). A similar system existed in the Soviet Union where a permit (propiska) was necessary for travel between regions and was used to slow the movement of individuals from rural areas to the cities (Human Rights Watch, 1998). Some questions that students could consider for this section include,

1. Is the right to travel or migrate a human right?

2. Is it ever justified for state or federal government to restrict travel within a state or nation?

3. Is it justified for state or federal government to restrict travel outside or re-enter the country? 
McCorkle, W., Problematizing Immigration Restrictions

4. Should nation states have the right to restrict travel in the absence of health and security concerns?

\section{Historical Examples of Policies During Chaotic Times}

Teachers can also focus on how these types of temporary policies of a nation could become an excuse for authoritarian immigration policies in the future. This is especially true if something like COVID-19 becomes endemic as the WHO says is possible (Howard \& Rahim, 2020). What happens if a reliable vaccine is not found? Even if the greatest danger has passed, will the issue of pandemics and viruses be used as an excuse to block more asylum-seekers and refugees in the future? As mentioned earlier in the paper, there are many examples of problematic responses to crises in U.S. History. Perhaps the closest historical precedent to compare to the current situation is 9/11, when the Patriot Act was immediately passed after the attacks and was used for years into the future for issues that did not even pertain to terrorism (Bell, 2011). Teachers could examine the rhetoric surrounding the Patriot Act following September $11^{\text {th }}$, the anti-terrorist rationale behind it, and the almost unanimous, immediate support for it. They could then examine in what ways it was used for its original purpose of stopping terrorism and conversely how it led to other purposes such as the NSA spying on all American citizens, which whistleblowers like Edward Snowden later exposed (Scheuerman, 2014). Another historical example that teachers could have students examine is the limitations on the First Amendment in the midst of World War I in the United States where speaking out against the war was met with resistance (Gutfeld, 1968) or similarly the McCarthyism of the 1950s where free political thought was also under attack (Gibson, 1988) in the name of security. In regard to immigration specifically, there could be an examination of how the fear and economic turmoil of the Great Depression contributed to the deportations of scores of individuals of Latin American descent, including U.S. citizens (Wagner, 2017). This restrictive immigration environment also caused the United States to turn away Jewish refugees fleeing the Nazi threat in Europe (Blakemore, 2019). There could be an analysis of how the events of 9/11 allowed for more restrictions on immigrant communities that extended far beyond the initial moves to secure the country including the establishment of ICE (Immigration and Customs Enforcement). It also created an environment where local and state officials became more involved with immigration enforcement (Mittelstadt, Speaker, Meissner, D., \& Chishti, 2011). This issue could be combined into the broader conversation of the effects of 9/11 both in the United States and around the world. Ettinger (2016) outlines methods for teaching students about the wars of 9/11 (Iraq and Afghanistan) who may have been too young to remember the events of 9/11. He believes this pedagogical reflection is of special importance for educators who may take aspects of this knowledge for granted since they lived through it.

\section{Table 1}

U.S. Responses to Crises

\begin{tabular}{|l|l|l|}
\hline Crisis & Intention & Secondary Results \\
\hline Resistance to World War I & Unity to Win War & $\begin{array}{l}\text { Limits on Free Speech, Free } \\
\text { Press, and Free Assembly }\end{array}$ \\
\hline
\end{tabular}




\begin{tabular}{|c|c|c|}
\hline Red Scare/McCarthyism & $\begin{array}{l}\text { Stop } \\
\text { Communism/Revolution }\end{array}$ & $\begin{array}{l}\text { Scapegoating of immigrants, } \\
\text { uncritical accusations, limits on } \\
\text { political thought }\end{array}$ \\
\hline $\begin{array}{l}\text { Great Depression/High } \\
\text { Unemployment }\end{array}$ & Help American Workers & $\begin{array}{lr}\text { Loss of rights for Mexican- } \\
\text { migrants } \\
\text { Mexican } \\
\text { rejection of americans) and } \\
\text { including Jews fleeing Nazi } \\
\text { Europe. }\end{array}$ \\
\hline September $11^{\text {th }}$ & $\begin{array}{l}\text { Stop Terrorism/Ensure } \\
\text { Security }\end{array}$ & $\begin{array}{lr}\text { Scapegoating of Muslim } \\
\text { Americans, infringements of civil } \\
\text { liberties, } & \text { government } \\
\text { surveillance, } & \text { creation of } \\
\text { stronger } & \text { immigration } \\
\text { enforcement } & \end{array}$ \\
\hline
\end{tabular}

Some questions students could consider include,

1. Why do times of chaos and panic often lead to actions that are in opposition to the values of a nation? Is this inevitable or can it be avoided?

2. What are the similarities and differences between the current pandemic and the environment after September $11^{\text {th }}$ ?

3. How do you think the current response to COVID-19, particularly related to immigration, will be viewed in history?

4. What role is historical empathy in measuring the historical reactions to times of chaos?

\section{Expanding Executive Power}

Finally, this crisis gives a space to focus on the role of the executive in regard to immigration policy. The U.S. Constitution and many state governments were rightfully leery of the power of the executive. However, in many areas such as national security and immigration, the power of the executive has continued to grow over time (Wilson, 2019). Students could examine what the long-term effects of this are on the ideas of representative democracy. This could be integrated within the larger focus on the rise of more authoritarian governments around the world and the possible power they have consolidated during this time. Davis (2019) highlights the need for social studies teachers to integrate the dangers of authoritarianism within the social studies classroom and focus on the need for civic engagement to counteract this trend. Some larger questions students could consider include,

1. How has executive power expanded in the United States since the end of World War II?

2. How much executive authority is given constitutionally to the president and how have presidents abused executive authority?

3. What legislative and judicial authorities has executive authority undermined or weakened?

4. Where does the authority to make immigration policy lie? 
McCorkle, W., Problematizing Immigration Restrictions

5. In terms of executive authority, what have been the greatest differences between the Trump, Obama, and Bush administrations?

\section{Conclusion}

This paper was finished in the summer of 2020 in the midst of the COVID-19 pandemic. It is certain that some of the realities will shift dramatically over the near future. Unfortunately, one thing will almost certainly continue - this crisis will be used for xenophobic purposes that will extend far beyond this immediate crisis. It will also be true that some of the pro-immigrant movement against draconian policies will be further muted both because this crisis will demand more attention and because there may be less public will to actually move in a more inclusive direction. During these times, social studies educators need to combat xenophobic rhetoric and continue to push for more inclusive immigration policies through both their classes and their broader activism. It would be shameful if one of the legacies of this pandemic is more permanently closed borders and greater disregard for asylum seekers and refugees. That is why it is a vital necessity that educators begin exploring these issues now when they might be the most uncomfortable yet urgent, lest they be forgotten.

\section{References}

Ahmed, K. (2020, May 2) Malaysia cites Covid-19 for rounding up hundreds of migrants. The Guardian. https://www.theguardian.com/globaldevelopment/2020/may/02/malaysiacites-covid-19-for-rounding-up-hundreds-of-migrants

Alper, A. (2020, March 28). Trump mulls quarantine for New York, parts of New Jersey and Connecticut. Reuters. https://www.reuters.com/article/us-health-coronavirus-usatrump/trump-mulls-quarantine-for-new-york-parts-of-new-jersey-and-connecticutidUSKBN21FOQL

Alvarez, P. (2020a, March 20). 13 changes to the US immigration system during the coronavirus pandemic. CNN. https://www.cnn.com/2020/03/18/politics/immigrationchanges-coronavirus/index.html

Alvarez, P. (2020b, August 12). Refugee admissions to the US resume after being on pause due to coronavirus. CNN. https://www.cnn.com/2020/08/12/politics/refugeeadmissions-coronavirus/index.html

Amaro, S. (2020, March 13). Trump's travel ban on many European countries is 'politically motivated,' analysts say. CNBC. https://www.cnbc.com/2020/03/13/trump-travel-banon-europe-is-politically-motivated-analysts-say.html

Anderson, S. (2020, June 8). How to limit a president's power over coronavirus. Forbes. https://www.forbes.com/sites/stuartanderson/2020/06/08/how-to-limit-a-presidentspower-over-immigration/\#2b26c1912531 
Asquith, J. (2020, April 2). Coronavirus travel update-Over $90 \%$ of people live under travel restrictions. Forbes. https://www.forbes.com/sites/jamesasquith/2020/04/02/aprilupdate-coronavirus-travel-update-90-of-countries-have-travelrestrictions/\#4c5fa4bf3024

Aydin, H., Ozfidan, B., \& Carothers, D. (2017). Meeting the challenges of curriculum and instruction in school settings in the United States. Journal of Social Studies Education Research, 8(3), 76-92. https://jsser.org/index.php/jsser/article/view/223

Banks, J. A. (2003). Teaching for multicultural literacy, global citizenship, and social justice. In The 2003 Charles Fowler Colloquium on Innovation in Arts Education. https://www.lib.umd.edu/binaries/content/assets/public/scpa/2003-banks.pdf

Basik, N. (2012). Open minds on open borders. Journal of International Migration and Integration, 14(3), 401-417.http://doi.org/10.1007/s12134-012-0246-4

Bell, M. (2011, September 7). Patriot act used to fight more drug dealers than terrorists.

Washington Post. https://www.washingtonpost.com/blogs/blogpost/post/patriot-actused-to-fight-more-drug-dealers-than-terrorists/2011/09/07/gIQAcmEBAK_blog.html

Blakemore, E. (2019, June 4). A ship of Jewish refugees was refused US landing in 1939. This was their fate. History Channel. https://www. history.com/news/wwii-jewishrefugee-ship-st-louis-1939

Bradburn, D. (2008). A clamor in the public mind: Opposition to the Alien and Sedition Acts. The William and Mary Quarterly, 65(3), 565-600. https://www.jstor.org/stable/i25096802

Bregman, R. (2016). Utopia for realists. Amsterdam: The Correspondent.

Bunzl, M. (2004). Counterfactual history: a user's guide. The American Historical Review, 109(3), 845-858.

Candelaria, C., Daly, M. C., \& Hale, G. (2013, March). Persistence of regional inequality in China. Federal Reserve Bank of San Francisco. https://www.frbsf.org/economicresearch/files/wp2013-06.pdf

Carens, J. H. (1987). Aliens and citizens: The case for open borders. The Review of Politics, 49(2), 251-273.

Chappell, B. (2020, June 30). EU sets new list of approved travel partners. The U.S. isn't on it. National Public Radio. https://www.npr.org/sections/coronavirus-live- 
updates/2020/06/30/883858231/eu-sets-new-list-of-approved-travel-partners-the-us-isnt-on-it

Chiu, A., \& Armus, T. (2020, April 22). Autopsies find first U.S. coronavirus death occurred in early February, weeks earlier than previously thought. Washington Post. https://www.washingtonpost.com/nation/2020/04/22/death-coronavirus-firstcalifornia/

Coleman, J. (2020, July 21). Visitors from 31 states now required to quarantine when visiting New York, New Jersey, Connecticut. The Hill. https://thehill.com/homenews/statewatch/508352-visitors-from-31-states-now-required-to-quarantine-when-visiting-new

Counts, G. (1932/1978). Dare the school build a new social order? Ferrer \& Simons.

Crucini, M. J., \& Kahn, J. A. (2003). Tariffs and the Great Depression revisited. https://papers.ssrn.com/sol3/papers.cfm?abstract_id=892580

Dabach, D. B., Fones, A., Merchant, N. H., \& Adekile, A. (2018). Teachers navigating civic education when students are undocumented: Building case knowledge. Theory \& Research in Social Education, 46(3), 331-373. https://doi.org/10.1080/00933104.2017.1413470

Dabach, D. B., Merchant, N. H., \& Fones, A. K. (2018). Rethinking immigration as a controversy. Social Education, 82(6), 307-314.

Davis, K. C. (2019). Democracy is not a spectator sport: The role of social studies in safeguarding the republic. Social Education, 83(4), 180-187.

Dewey, J. (1897). My pedagogic creed (No. 25). EL Kellogg \& Company.

https://acurriculumjourney.files.wordpress.com/2014/04/dewey-1897-my-pedagogiccreed.pdf

Ettinger, A. (2016). Teaching the post-September 11 wars to the post-September 11 generation. Politics, 36(2), 197-209. http://doi.org/10.1111/1467-9256.12103

Fortier, A. (2006). The politics of scaling, timing and embodying: Rethinking the 'new Europe'. Mobilities, 1(3), 313-331. https://doi.org/10.1080/17450100600915992

Freire, P. (1970/1986). Pedagogy of the Oppressed, trans. Myra Bergman Ramos. New York: Continuum.

Galston, W. A. (2017). The 2016 US election: the populist moment. Journal of Democracy, 28(2), 21-33. https://www.journalofdemocracy.org/wpcontent/uploads/2017/04/03_28.2_Galston-web-002.pdf 
Garreton, A., Ryan, J., \& Carmel, B. (2020). Homeland insecurity (Podcast). RAICES. https://art19.com/shows/homeland-insecurity

Gibson, J. L. (1988). Political intolerance and political repression during the McCarthy Red Scare. American Political Science Review, 82(2), 511-529.

Girdap, H. (2020). Human Rights, Conflicts, and Dislocation: The Case of Turkey in a Global Spectrum . American Journal of Qualitative Research, 4(1), 69-

84. https://doi.org/10.29333/ajar/8266

Greene, E. (2020, April 16). U.S. and Mexico are blocking kids from asking for asylum because of the Coronavirus. The Intercept.

https://theintercept.com/2020/04/16/coronavirus-mexico-border-children-asylum/

Guadiano, N. Perez Jr., J., Stratford, M. (2020, July 8). Trump threatens to cut federal funds from schools that don't reopen. Politico.

https://www.politico.com/news/2020/07/08/trump-schools-reopening-federalfunding-352311

Gutfeld, A. (1968). The Ves Hall Case, Judge Bourquin, and the Sedition Act of 1918. Pacific Historical Review, 37(2), 163-178.

https://online.ucpress.edu/phr/article/37/2/163/75136/The-Ves-Hall-Case-JudgeBourquin-and-the-Sedition

Guttentag, L. (2020, April 13). Coronavirus border expulsions: CDC's assault on asylum seekers and unaccompanied minors. Just Security.

https://www.justsecurity.org/69640/coronavirus-border-expulsions-cdcs-assault- onasylum-seekers-and-unaccompanied-minors/

Holpuch, A. (2020, February 25). Trump's separation of families constitutes torture, doctors find. The Guardian. https://www.theguardian.com/us-news/2020/feb/25/trumpfamily-separations-children-torture-psychology

Howard, J. \& Rahim, Z. (2020, May 14). Coronavirus may 'never go away,' says WHO official. CNN. https://www.cnn.com/2020/05/14/health/coronavirus-endemic-whomike-ryan-intl/index.html

Hurley, L. (2020, March 11). U.S. Supreme Court allows Trump's 'Remain in Mexico' asylum policy. Reuters. https://www.reuters.com/article/us-usa-court-immigration/u-ssupreme-court-allows-trumps-remain-in-mexico-asylum-policy-idUSKBN20Y2ZA

Human Rights Watch (2020, April 2). https://www.hrw.org/news/2020/04/02/us-covid-19policies-risk-asylum-seekers-lives 
Human Rights Watch (1998). The residence permit system (Propiska). https://www.hrw.org/legacy/reports98/russia/srusstest-04.htm

Jordan, M. (2020, May 18). California offers $\$ 500$ in Covid-19 aid to undocumented immigrants. New York Times. https://www.nytimes.com/2020/05/18/us/coronavirusundocumented-california.html

Journell, W., \& Castro, E. L. (2011). Culturally Relevant Political Education: Using Immigration as a Catalyst for Civic Understanding. Multicultural Education, 18(4), 10-17.

Juss, S. S. (2004). Free movement and the world order. International Journal of Refugee Law, 16(3), 289-335.

Kelleher, S.R. (2020, April 5). South Carolina governor orders hotels not to accept guests from New York tri-state area. Forbes https://www.forbes.com/sites/suzannerowankelleher/2020/04/05/south-carolinagovernor-orders-hotels-not-to-accept-guests-from-new-york-tri-statearea/\#55b885362ab9

Kessler, G. (2020, April 7). Trump's claim that he imposed the first 'China ban.' Washington Post. https://www. washingtonpost.com/politics/2020/04/07/trumps-claim-that-heimposed-first-china-ban/

Kilinc, E., Tarman, B., \& Aydin, H. (2018). Examining Turkish social studies teachers' beliefs about barriers toTechnology integration. TechTrends, 62(3), 221-

223. https://doi.org/10.1007/s11528-018-0280-y

Kocher, A. (2017). The new resistance: Immigrant rights mobilization in an era of Trump. Journal of Latin American Geography, 16(2), 165-171. https://doi.org/10.1353/lag.2017.0027

Kraut, A. M. (2010). Immigration, ethnicity, and the pandemic. Public health reports, 125(3_suppl), 123-133. https://doi.org/10.1177/00333549101250s315

Lakhani, N. (2020, April 17). U.S. using coronavirus pandemic to unlawfully expel asylum seekers, says UN. The Guardian.

https://www.theguardian.com/world/2020/apr/17/us-asylum-seekers-coronaviruslaw-un

Leung, H. (2020, April 29). Singapore was a coronavirus success story-Until an outbreak showed how vulnerable workers can fall through the cracks. Time.

https://time.com/5825261/singapore-coronavirus-migrant-workers-inequality/ 
Lind, D. (2018, June 26). How Trump's travel ban became normal. Vox. https://www.vox.com/2018/4/27/17284798/travel-ban-scotus-countries-protests

Malagon, E. \& Husain, N. (2020, April 27). Refugees try to make new start in Chicago as COVID-19 upends daily life: 'Once we get back to the normal life, we want to walk freely.' https://www.chicagotribune.com/coronavirus/ct-coronavirus-chicago-refugeeresettlement-20200427-shnxyib525dhlldcohla2ewwte-story.html

McCorkle, W. (2020). Introducing Students to Critical Border and Migration Theories in an Era of Xenophobia. Critical Questions in Education, 11(1). https://academyedstudies.files.wordpress.com/2020/02/mccorklefinal.pdf

McCorkle, W. D. (2019). Reframing Immigration as an Issue of Freedom within the US Classroom. Journal of International Social Studies, 9(2), 107-123. https://iajiss.org/index.php/iajiss/article/download/451/327

McCorkle, W., Cole, M. W., \& Spearman, M. (2018). Confronting false narratives in the debate over immigration. Social Education, 82(6), 348-354. https://www.socialstudies.org/system/files/publications/articles/se_8206348.pdf

McCorkle, W. (2018a). Teachers' awareness and attitudes towards rights for immigrant students (Doctoral Dissertation). Clemson University, Clemson SC. https://tigerprints.clemson.edu/cgi/viewcontent.cgi?article=3207\&context=all_dissert ations

McCorkle, W. (2018b). The rationale and strategies for undermining xenophobia in the classroom. The Social Studies, 109(3), 151-166. https://doi.org/10.1080/00377996.2018.1472062

Merchant, N. (2020, July 22). Migrant kids held in US hotels, then expelled. AP News. https://apnews.com/c9b671b206060f2e9654f0a4eaeb6388

Mittelstadt, M., Speaker, B., Meissner, D., and Chishti, M. (2011, August). Through the prism of national security: Major immigration policy and program changes in the decade since 9/11. Migration Policy Institute. https://www.migrationpolicy.org/research/post9-11-immigration-policy-program-changes

Montoya-Galvez, C. (2020, March 30). Citing coronavirus, the U.S. is swiftly deporting unaccompanied migrant children. CBS News.

https://www.cbsnews.com/news/coronavirus-us-swiftly-deporting-unaccompaniedmigrant-children-citing-covid-19/ 
McCorkle, W., Problematizing Immigration Restrictions

Monreal, T., \& McCorkle, W. (2020). Social Studies Teachers' Attitudes and Beliefs About Immigration and the Formal Curriculum in the United States South: A Multi-Methods Study. The Urban Review, 1-42. https://doi.org/10.1007/s11256-020-00561-3

Nast, P. (2012). War and migration. National Educational Association. http://www.nea.org/tools/lessons/63678.htm

National Council for the Social Studies (2010). National curriculum standards for social studies: Chapter 2-the themes of social studies.

https://www.socialstudies.org/national-curriculum-standards-social-studies-chapter2-themes-social-studies\#3

Ngai, M. (2014). Undocumented migration to the U.S.: A history. In L. Lorentzen (Ed.), Hidden lives and human rights in the United States [3 volumes]: Understanding the controversies and tragedies of undocumented immigration. Santa Barbara, CA: Praeger. https://bit.ly/3mWTfPa

Nieto del Rio, G.M. \& Ellis, R. (2020, March 28). Rhode Island will knock on doors and stop cars to find New Yorkers to slow the spread of coronavirus. CNN. https://www.cnn.com/2020/03/27/us/rhode-island-tracking-down-newyorkers/index.html

Pallini, T. (2020, April 4). Photos show the emergency makeshift borders European countries have erected in an attempt to stop the spread of COVID-19. Business Insider. https://www.businessinsider.com/coronavirus-european-borders-closed-in-responseto-covid-19-2020-4

Parker, N., \& Vaughan-Williams, N. (2012). Critical border studies: Broadening and deepening the 'lines in the sand' agenda. Geopolitics, 17(4), 727. https://doi.org/10.1080/14650045.2012.706111

Parmar, A. (2020). Borders as Mirrors: Racial Hierarchies and Policing Migration. Critical Criminology, 1-18. https://doi.org/10.1007/s10612-020-09517-1

Peña, A. (2020, June 30). First COVID-19 case confirmed in asylum seeker camp at U.S.Mexico border. Time. https://time.com/5862084/asylum-seekers-u-s-mexico-bordercovid-19/

Poteat, V. P., Calzo, J. P., Yoshikawa, H., Rosenbach, S. B., Ceccolini, C. J., \& Marx, R. A. (2019). Extracurricular settings as a space to address sociopolitical crises: the case of discussing immigration in Gender-Sexuality Alliances following the 2016 US presidential election. American Educational Research Journal, 56(6), 2262-2294. https://doi.org/10.3102/0002831219839033 
Pyun, J.H., \& Lee, J.W. (2009). Globalisation promotes peace. CEPR Policy Portal. https://voxeu.org/article/globalisation-promotes-peace

Re, G. (2020, April 1). After attacking Trump's coronavirus-related China travel ban as xenophobic, Dems and media have changed tune. Fox News.

https://www.foxnews.com/politics/dems-media-change-tune-trump-attackscoronavirus-china-travel-ban

Rhodes, B. (2020, April 6). The 9/11 era is over. The Atlantic. https://www.theatlantic.com/ideas/archive/2020/04/its-not-september-12anymore/609502/

Roberts, S. L. (2011). Using counterfactual history to enhance students' historical understanding. The Social Studies, 102(3), 117-123. https://doi.org/10.1080/00377996.2010.525547

Romo, V. (2020, April 20). U.S. And Mexico Extend Coronavirus Border Restrictions For Another Month. NPR. https://www.npr.org/sections/coronavirus-liveupdates/2020/04/20/838868307/u-s-and-mexico-extend-coronavirus-borderrestrictions-for-another-month

Saeed, S. (2020, March 13). Trump's Europe travel ban explained. Politico. https://www.politico.eu/article/coronavirus-donald-trump-europe-travel-banexplained/

Scharping, N. (2020, March 30). Could we be living with COVID-19 forever? Discover Magazine. https://www.discovermagazine.com/health/could-we-be-living-with-covid19-forever

Scheineson, A., \& Zissis, C., (2009, May 14). China's internal migrants. Council of Foreign Relations. https://www.cfr.org/backgrounder/chinas-internal-migrants

Scheuerman, W. E. (2014). Whistleblowing as civil disobedience: The case of Edward Snowden. Philosophy \& Social Criticism, 40(7), 609-628.

https://doi.org/10.1177/0191453714537263

Schmitt, A., \& Massimino, E. (2020, April 10). A migrant model to follow: Portugal's response to the coronavirus. Center for American Progress. https://www.americanprogress.org/issues/security/news/2020/04/10/482998/migran t-model-follow-portugals-response-coronavirus/

Schulze Wessel, J. (2016). On border subjects: Rethinking the figure of the refugee and the undocumented migrant. Constellations, 23(1), 46-57. https://doi.org/10.1111/14678675.12182 
McCorkle, W., Problematizing Immigration Restrictions

Shear, M.D., Kanno-Youngs, S., \& Dickerson, C. (2020, April 21). Trump halts new green cards, but backs off broader immigration ban. New York Times.

https://www.nytimes.com/2020/04/21/us/politics/coronavirus-trump-immigrationban.html

Sherlock, R. (2020, May 5). Migrants are among the worst hit by COVID-19 in Saudi Arabia and gulf countries. National Public Radio. https://www.npr.org/sections/coronaviruslive-updates/2020/05/05/850542938/migrants-are-among-the-worst-hit-by-covid-19in-saudi-arabia-and-gulf-countries

Snyder, T. (2020, March 14). White House adds U.K., Ireland to travel ban, hints at airline aid. Politico. https://www. politico.com/news/2020/03/14/white-house-adds-ukireland-to-travel-ban-129470.

Statista (2020). COVID-19 cases and deaths among hardest hit countries worldwide as of August 24, 2020. https://www.statista.com/statistics/1105264/coronavirus-covid-19cases-most-affected-countries-worldwide/

Storesletten, K. (2000). Sustaining fiscal policy through immigration. Journal of Political Economy, 108(2), 300-323. http://dx.doi.org/10.1086/262120

Tarman, B. (2020). Reflecting in the shade of pandemic. Research in Social Sciences and Technology, 5(2), i-iv. https://doi.org/10.46303/ressat.05.02.ed

Tarman, B., \& Gürel, D. (2017). Awareness of social studies teacher candidates on refugees in Turkey. The Journal of Social Studies Research, 41(3), 183-193.

https://doi.org/10.1016/j.jssr.2016.11.001

Tidman, Z. (2020, May 5). Hospital case suggests coronavirus spread to Europe earlier than thought. The Independent.

https://www.independent.co.uk/news/world/europe/france-coronavirus-parishospital-cases-december-deaths-latest-a9499406.html

United Nations Human Rights Office of the High Commissioner (N.D.). The principle of nonrefoulement under international human rights law.

https://www.ohchr.org/Documents/Issues/Migration/GlobalCompactMigration/ThePri ncipleNon-RefoulementUnderInternationalHumanRightsLaw.pdf

Von der Leyen, U., \& Michel, C. (2020, March 12). Joint Statement by President von der Leyen and President Michel on the U.S. travel ban. European Commission. https://ec.europa.eu/commission/presscorner/detail/en/statement_20_449 
Wagner, A. (2017, March 6). America's forgotten history of illegal deportations. The Atlantic. https://www.theatlantic.com/politics/archive/2017/03/americas-brutal-forgottenhistory-of-illegal-deportations/517971/

White, A. (2004). Teaching students to read the news via representations of asylum seekers in British newspapers. Journal of Geography in Higher Education, 28(2), 285-299. http://dx.doi.org/10.1080/0309826042000242512

White, C.S. (2020). Wielding social media in the cyber-arena: Globalism, nationalism, and civic education? Research in Social Sciences and Technology, 5(1),1-21. https://ressat.org/index.php/ressat/article/view/438

Wilson, G. (2019). Unitary Theory, Consolidation of Presidential Authority, and the Breakdown of Constitutional Principles in Immigration Law. Immigration and Human Rights Law Review, 1(2), 4. https://scholarship.law.uc.edu/ihrlr/vol1/iss2/4

Woods, R. B. (1987). Fulbright internationalism. The Annals of the American Academy of Political and Social Science, 491(1), 22-35.

Yen, H. (2020, March 26). AP News check: Trump's inaccurate boasts on China travel ban. Associated Press. https://apnews.com/0dc271ad7f7917374a5a0cfb49273783 